\title{
Pengawasan Profesional Kepala Sekolah Dalam Meningkatan Mutu Pembelajaran
}

\author{
Besse Marhawati ${ }^{1}$, Sulkifly ${ }^{2}$ \\ ${ }^{1,2}$ Fakultas Ilmu Pendidikan Universitas Negeri Gorontalo \\ Email: Besse@ung.ac.id
}

\begin{abstract}
ABSTRAK
Penelitian ini bertujuan untuk mendeskripsikan Pengawasan professional kepala sekolah dalam peningkatan mutu pembelajaran guru yang meliputi: (1) Membantu guru mengatasi kesulitan mengajarnya dalam menyesuaikan dengan tuntutan perubahan baru; (2) Melakukan penilaian terhadap sasaran program pengajaran yang disesuaikan dengan kebutuhan belajar (3) Melakukan perbaikan program pengajaran yang telah direncanakan (4) Melakukan programprogram perubahan dan (5) Melakukan evaluasi terhadap program-program pengajaran. Pendekatan yang digunakan adalah pendekatan kualitatif dengan rancangan studi kasus yang berlokasi di MIM Unggulan Kota Gorontalo. Hasil penelitian menunjukkan: Upaya kepala sekolah (1) membantu guru yang mengalami kesulitan mengajar (Menggabungkan ke group, sharing ilmu, penggunaan model, metode, dan teknik pemlelajaran), menyiapkan laptop dan LCD di kelas, penyediaan buku paket, pelatihan pembuatan video-video pembelajaran, mendesain pembelajaran yang menyenangkan, dan penyediaan jaringan listrik dan internet (WIFI) dan Indi Home; (2) melakukan penilaian terhadap sasaran program pengajaran meliputi: melakukan supervisi administrasi dan supervisi kelas, pemantauan melalui CCTV dan pemantauan langsung ke kelas, bimbingan khusus terhadap siswa-siswa yang memiliki bakat dan potensi untuk persiapan dalam mengikuti lomba; (3) program-program perubahan meliputi: bimbingan khusus bagi siswa yang orang tuanya ingin mengikutkan anaknya dalam bimbingan di bidang matematika, sains, tilawah, bimbingan khusus juga dilakukan bagi siswa-siswa yang memiliki keinginan sendiri, penilaian karakter siswa; (4) Melakukan program-program perubahan meliputi: kerjasama dengan sekolah, perguruan tinggi dan lembaga bimbingan belajar, raport digital, kultum setelah sholat Dzuhur, proaktif dalam mengikuti lomba-lomba, penilaian sikap berbas is IT melalui aplikasi Dojo Class, absensi online, group kelas, akun untuk guru, siswa, dan orang tua, dan program hafalan Qur'an juz 30; dan (5) Melakukan evaluasi terhadap program-program meliputi: rapat evaluasi dalam hal ini membahas tentang kendala terhadap program pengajaran yang telah direncanakan, dan kegiatan Problem Solving setiap hari Ju'mat.
\end{abstract}

Kata Kunci: Professional; Kepala Sekolah; Mutu Pembelajaran

\begin{abstract}
ABSTRAC
This study aims to describe the professional supervision of principals in improving the quality of teacher learning which includes: (1) the efforts of the principal to help teachers overcome their teaching difficulties in adjusting to the demands of new changes; (2) the efforts of the principal in assessing the target of the teaching program tailored to the learning needs of students; (3) the efforts of the principal in making improvements to the teaching programthat has been planned (4) the efforts of the principal in implementing change programs; and (5) the principal's efforts to evaluate teaching programs. The approach used in this research is a qualitative approach with a case studydesign located. The results showed: (1) the efforts of the principal to help teachers overcome their teaching difficulties in adjusting to the demands of new changes. At MIM Unggulan Kota Gorontalo, include: helping teachers who have difficulty teaching (Merging into groups, sharing knowledge, using models, methods, and learning techniques), preparing laptops and LCDs in the classroom, providing textbooks, training making learning videos, designing fun lessons, and providing electricity and internet networks (WIFI) and Indi Home; (2) the efforts of the principal in assessing the target of the teaching program tailored to the learning needs of student s de: administrative supervision and classroom supervision, monitoring via CCTV and direct monitoring to the class, special guidance for students. students who have the talent and potential for preparation for participating in competitions; (.3) The efforts of the principal to carry out change programs: special guidance for students whose parents want to include theirchildren
\end{abstract}

Pedagogika.fip@ ung.ac.idＰ-ISSN:2086-4469Ｅ-ISSN: 2716-0580 


\section{PEDAGOGIKA}

Volume 12 (Nomor 2) 2021

HaL. 245-263

in guidance in the fields of mathematics, science, recitation, special guidance is also carried out for students who have theirown desires, assessment of student character; (4) the efforts of the principal to carry out change programs: cooperation with schools, colleges and tutoring institutions, digital report cards, cult after Dzuhur prayer, proactive in participating in competitions, IT-based attitude assessment through the Dojo Class application, online attendance, class groups, accounts for teachers, students and parents, and the memorization program of the Qur'an juz 30; and (5) the principal's efforts to evaluate teaching programs: evaluation meetings in this case discussing the obstacles to the planned teaching program, and Problem Solving activities every Ju'mat day.

Keyword: Professional; Headmaster; Learning Quality

(C2021 Besse Marhawati, Sulkifly

Unther The License CC BY-SA 4.0

\section{PENDAHULUAN}

Guru merupakan titik sentral dalam usaha mereformasi pendidikan, dan mereka menjadi kunci keberhasilan setiap usaha peningkatan mutu pendidikan. Apapun namanya, apakah itu pembaharuan kurikulum, pengembangan metode-metode mengajar, peningkatan pelayanan pembelajaran, penyediaan buku teks, hanya akan berarti apabila melibatkan guru (Departemen Pendidikan dan Kebudayaan, Badan Perencanaan Pembangunan Nasional dan Bank Dunia dalam Suhardan, 2010:13).

Hal tersebut mengisyarakan bahwa mutu pembelajaran, merupakan masalah yang urgen. Untuk itu guru harus mendapat pengawasan dan pembinaan yang terus menerus dan berkelanjutan melalui pengawasan profesional dalam rangka memperbaiki mutu pembelajarannya.

Pengawasan profesional yang dilaksanakan melalui supervisi pendidikan sebagai usaha memperbaiki dan meningkatkan mutu mengajar yang terarah pada perbaikan perilaku kinerja profesional guru. Sebagaimana dikatakan oleh Sagala, 2012:104) bahwa; tujuan inti dari supervisi pengajaran adalah membantu guru meningkatkan kualitas profesionalnya dalam mengajar.

Upaya meningkatkan kemampuan profesional guru harus dilakukan dengan cara pengawasan profesional dengan mekanisme penerapan fungsi supervisi, sebab kegiatan supervisi membutuhkan keahlian dalam memahami kegiatan pembelajaran yang bersifat akademik. Pengawasan profesional diharapkan akan berdampak pada peningkatan mutu proses dan mutu hasil belajar, mengingat mutu pembelajaran merupakan refleksi dari kemampuan profesional guru dalam melaksanakan tugas mengajarnya.

Ada beberapa aspek penting dalam kegiatan supervisi yaitu: (1) bersifat bantuan dan pelayanan kepala sekolah kepada guru dan 


\section{PEDAGOGIKA}

Volume 12 (Nomor 2) 2021

HaL. 245-263

staf, (2) untuk pengembangan kualitas guru, (3) untuk pengembangan profesional guru, dan (4) untuk memotivasi guru. Aspek-aspek tersebut menuntut pengetahuan tentang konsep dan pendekatan supervisi yang ditunjang dengan kinerja dan akuntabilitas yang tinggi dari supervisor. Hal ini dimaksudkan agar kegiatan supervisi sebagai layanan profesional dapat meningkatkan kompetensi guru dalam pembelajaran yang bermuara pula pada perwujudan hasil belajar peserta didik secara optimal. (Masaong, 2012: 3).

Bimbingan profesional yang dilakukan kepala sekolah sebagai supervisor terhadap guru adalah sebagai usaha yang memberikan kesempatan bagi guru untuk berkembang secara profesional, sehingga mereka lebih maju lagi dalam melaksanakan tugas pokoknya. Para guru menjadi mampu dan mau memperbaiki serta meningkatkan kemampuan belajar peserta didiknya. Untuk itu dilakukan penelitian dengan judul: Pengawasan Profesional Kepala Sekolah Dalam Peningkatan Mutu Pembelajaran Guru yang akan dilakasanakan Di Madrasah Ibtidaiyah Muhammadiyah Unggulan Kota Gorontalo.

Pengawasan profesional yang dilaksanakan melalui supervisi pendidikan sebagai usaha memperbaiki dan meningkatkan mutu mengajar yang terarah pada perbaikan perilaku kinerja profesional guru. Sebagaimana dikatakan oleh Sagala, 2012:104) bahwa; tujuan inti dari supervisi pengajaran adalah membantu guru meningkatkan kualitas profesionalnya dalam mengajar.

Ada beberapa aspek penting dalam kegiatan supervisi yaitu: (1) bersifat bantuan dan pelayanan kepala sekolah kepada guru dan staf, (2) untuk pengembangan kualitas guru, (3) untuk pengembangan profesional guru, dan (4) untuk memotivasi guru. Aspek-aspek tersebut menuntut pengetahuan tentang konsep dan pendekatan supervisi yang ditunjang dengan kinerja dan akuntabilitas yang tinggi dari supervisor. Hal ini dimaksudkan agar kegiatan supervisi sebagai layanan profesional dapat meningkatkan kompetensi guru dalam pembelajaran yang bermuara pula pada perwujudan hasil belajar peserta didik secara optimal. (Masaong, 2012: 3).

Walaupun sebenarnya guru telah memiliki bekal pengetahuan, kemampuan maupun keterampilan yang cukup yang diperoleh selama masa pendidikan pra jabatan maupun pengalaman tambahan dalam bekerja, baik dalam bentuk penataran maupun pengembangan diri. Namun demikian dalam melaksanakan tugas mengajarnya guru-guru sering mengalami kesulitan untuk 


\section{PEDAGOGIKA}

Volume 12 (Nomor 2) 2021

HaL. 245-263

menyesuaikan pengetahuan yang dimilikinya dengan kebutuhan pembelajaran di sekolah yang berbeda dengan pengalaman belajar yang ditemukannya. Perkembangan dan perubahan serta kebijakan baru dalam pelaksanaan pembelajaran di sekolah juga menuntut kemampuan baru untuk dilaksanakan. Masalah seperti ini menuntut kemampuan kepala sekolah untuk selalu melakukan pembinaan terhadap guru-gurunya agar mutu pendidikan di sekolah berjalan sesuai dengan tuntutan mutu yang diinginkan oleh tuntutan baru yang sedang berkembang. Tuntutan perkembangan ini membutuhkan kemampuan profesional untuk menyesuaikannya. Banyak guru telah berusaha memecahkan kesulitan dengan caranya sendiri. Pemecahan masalah seperti ini merupakan tindakan individual yang tidak akan menghasilkan perubahan kelembagaan secara menyeluruh.

Bantuan berupa perbaikan teknis metodologis pembelajaran, pemecahan kesulitan individual, pengayaan atau pengembangan kurikulum, penguasaan materi ajar, pembuatan lembar kerja, penggunaan sumber belajar maupun pemilihan buku teks. Apabila guru selama bertugas tidak memperoleh bantuan profesional yang teratur, sangat mungkin pada suatu saat pengetahuan, keterampilan, dan kemampuan yang dimiliki sebagai bekal pendidikan pra jabatan tidak lagi berkembang atau terhenti karena keletihan, kejenuhan, atau kebosanan bahkan mungkin terjadi penurunan prestasi. Hal seperti ini sangat merugikan bagi usaha peningkatan mutu pendidikan (Suhardan, 2010:84-85).

Dalam melakukan kegiatan supervisi, seorang supervisor harus memahami sepenuhnya sepuluh kemampuan dasar guru dan kompetensi guru. Sepuluh kemampuan dasar guru yaitu: (1) menguasai landasanlandasan pendidikan, (2) menguasai bahan pelajaran, (3) kemampuan mengelola program belajar mengajar, (4) kemampuan mengelola kelas, (5) kemampuan mengelola interaksi belajar mengajar, (6) menilai hasil belajar siswa, (7) kemampuan mengenal dan menerjemahkan kurikulum, (8) mengenal fungsi dan program bimbingan dan penyuluhan, (9) memahami prinsip-prinsip dan hasil pengajaran, dan (10) mengenal dan menyelenggarakan administrasi pendidikan. Sedangkan kompetensi guru meliputi: kompetensi pedagogik, kompetensi kepribadian, kompetensi sosial dan kompetensi professional. Hal ini penting bagi supervisor agar pelaksanaan pendidikan dan pengajaran dapat dipertanggung jawabkan kepada masyarakat. Tanggung jawab terhadap kompetensi profesional guru untuk mengajar 


\section{PEDAGOGIKA}

Volume 12 (Nomor 2) 2021

HaL. 245-263

dan mendidik merupakan tuntutan masyarakat terhadap efektivitas pengajaran. Makanya kepekaan kepala sekolah sebagai supervisor terhadap profesionalisasi jabatan guru, menuntut profesionalisasi guru, dengan demikian supervisi pendidikan dituntut untuk memberikan perhatian khusus memperbaiki pengajaran sehingga tercipta kualitas yang baik (Sagala, 2012: 115-116).

Hasil-hasil penelitian Lipham (dalam Sagala, 2012:134-135) berkaitan dengan kinerja kepala sekolah yang berhasil adalah kepala sekolah yang memiliki komitmen yang kuat terhadap peningkatan kualitas pengajaran. Komitmen yang kuat menggambarkan adanya kemauan dan kemampuan melakukan monitoring pada semua aktivitas semua personel sekolah. Misalnya dalam pengajaran dilakukan dengan cara memonitor waktuwaktu dan proses pengajaran di kelas, sehingga menjamin efektivitas pelaksanaan program pengajaran dan layanan belajar yang berkualitas di kelas. Kepala sekolah yang memiliki kemampuan cukup akan dapat mengatasi problem pengembangan kurikulum yang merespon perubahan-perubahan yang terjadi. Perubahan-perubahan itu harus direspon dalam tujuan pembelajaran dan tujuan sekolah, isi materi pelajaran, metode, dan pendekatan dalam pengajaran, evaluasi, dan kegiatan lainnya yang berkaitan dengan layanan belajar. Untuk mengatasi semua permasalahan pendidikan di sekolah, maka para guru memerlukan bantuan dan bimbingan dari kepala sekolah berupa layanan supervisi sebagai bentuk tanggung jawab profesional.

Berkaitan dengan tanggung jawab profesional kependidikan tersebut, lebih lanjut Lipham merekomendasikan empat fase proses pembinaan pengajaran yaitu: (1) assessing program objectives, penilaian terhadap sasaran program, kepala sekolah perlu menguji apakah program pengajaran sudah sesuai dengan kebutuhan belajar peserta didik, (2) planning program improvement, perbaikan programprogram yang direncanakan dengan cara membentuk struktur kerja yang tepat, menghimpun informasi dan data-data yang akurat mengenai pembelajaran dan memanfaatkannya untuk melakukan perbaikan dan penyusunan program sesuai spesifikasi sumber-sumber yang diperlukan oleh program, (3) implementing program change, melakukan program-program perubahan dengan cara memotivasi para guru untuk menggunakan strategi pengajaran yang lebih menarik dan interaktif, memotivasi staf sekolah untuk memberikan layanan yang terbaik dalam mendukung lancarnya kegiatan belajar dan mengajar, dan memotivasi masyarakat sekolah 


\section{PEDAGOGIKA}

Volume 12 (Nomor 2) 2021

HaL. 245-263

untuk memberi dukungan penuh terhadap program-program peningkatan mutu pmbelajaran di sekolah, dan (4) evaluation of program change, melakukan evaluasi terhadap program-program apakah telah terjadi perubahan dengan cara mengukur outcomes dari pengajaran yang telah dilakukan.

Pemberdayaan guru merupakan usaha untuk mempertinggi kecakapan guru dalam mengemban profesinya. Pemberdayaan guru profesional merupakan suatu usaha agar guru memperoleh kewenangan mengajar sesuai standar profesional. Kemampuan mengajar guru perlu memperoleh pembinaan supaya mereka memiliki kewenangan mengajar sesuai dengan tuntutan zaman. Di era ini guru dituntut lebih kritis dan aktif dalam menjalankan tugasnya, pembinaan terhadap mereka menjadikan guru bukan sekedar pelaksana teknis, melainkan seorang petugas profesional yang mengerti dan memahami bagaimana seharusnya memberi layanan belajar kepada peserta didiknya. Guru yang berdaya mempunyai kepekaan terhadap kebutuhan peserta didiknya, dan sanggup mencari solusi dari kesulitan mengajar yang dihadapinya. Hal ini disebabkan tugas guru sehari-hari melaksanakan layanan belajar kepada peserta didik sesuai dengan tujuan pendidikan yang dituangkan kedalam kurikulum, menyajikannya berdasarkan metode mengajar dan menilai kemajuan untuk mengetahui ketercapainnya. Bila mereka tidak diberdayakan, maka guru akan larut dalam sistem yang rutin, sehingga tidak mustahil akan mengalami kejenuhan dan prestasinya akan menurun karena kraetivitasnya menjadi tumpul (Suhardan, 2010: 87).

Ada beberapa masalah yang dihadapi guru dalam implementasi kurikulum 2013 terutama pencapaian yaitu: (1) standar isi, yaitu guru kurang memahami kerangka dasar dan struktur kurikulum, ketidakcukupan waktu karena muatan isi terlalu luas, penanaman konsep karena tidak didukung oleh informasi teknologi; (2) standar proses, yaitu guru mengalami kesulitan dalam mengembangkan RPP, penerapan pembelajaran saintifik, tematik terpadu, kontruktifiktis, penggunaan media laptop dan LCD; (3) standar kompetensi lulusan, yaitu kesulitan dalam mengembangkan kompetensi sikap, pengetahuan dan keterampilan secara terpadu; (4) standar penilaian, yaitu kesulitan dalam membuat soal tes dan menyusun instrumen non-tes, melaksanakan penilaian proses karena jumlah siswa dalam rombongan belajar terlalu banyak. Sedangkan kerangka model supervisi pembelajaran untuk membantu memecahkan masalah guru meliputi penerapan supervisi 


\section{PEDAGOGIKA}

Volume 12 (Nomor 2) 2021

HaL. 245-263

kelompok, kemudian untuk guru yang menghadapi masalah khusus diterapkan model supervisi individual (Maisyaroh, dkk, 2014:219).

Kepala sekolah memiliki tugas untuk meningkatkan keberhasilan keseluruhan program pembelajaran sekolah dan kemajuan guru dan siswa. Hal ini dilakukan oleh kepala sekolah melalui penekanan program pembelajaran yang unggul, mendiagnosa program pembelajaran berkelanjutan, berdiskusi mengenai program pembelajaran dengan guru, dan membantu guru dalam mengidentifikasi tujuan pembelajaran serta gagasan dan pengalaman dengan guru tentang kurikulum dan masalah pembelajaran lain (Sobri, 2013: 19).

\section{METODE PENELITIAN}

\section{Pendekatan dan Rancangan Penelitian}

Penelitian ini akan dilaksanakan di MIM Unggulan Kota Gorontalo. Pendekatan Penelitian yang akan digunakan pada penelitian ini adalah pendekatan kualitatif dimana pendekatan ini memerlukan pengamatan mendalam pada situasi yang wajar (Natuaralistic setting). Penelitian ini menggunakan rangcangan studi kasus. Dimana studi kasus ini memungkinkan peneliti untuk bisa mempelajari karakteristik yang akan diteliti secara menyeluruh sehingga dapat bermakna terhadap peristiwa-peristiwa kehidupan nyata.

\section{Teknik Pengumpulan Data}

Prosedur pengumpulan data yang digunakan dalam penelitian ini adalah: (1) Guba dan Lincoln (1981) dalam Ulfatin, (2013:184) menjelaskan alasan digunakannya wawancara dalam penelitian kualitatif antara lain untuk mengkonstruksi seseorang, kejadian, organisasi, perasaan, motivasi, tuntutan, kepedulian, dan lain-lain sebagai kebulatan yang dialami pada masa lalu, memproyeksikan kebulatan sebagai yang diharapkan untuk dialami di masa yang akan datang, dan memverifikasi, mengubah atau memperluas informasi yang diperoleh dari orang lain.wawancara, (2) Observasi, . Dalam penelitian, pengamatan, pengamatan dapat diartikan sebagai melihat pola perilaku manusia atau obyek dalam suatu situasi untuk mendapatkan informasi tentang fenomena yang diamati (Ulfatin, 2013:204).dan

dokumentasi. yaitu Dokumen bisa berupa tulisan, gambar, atau karya monumental dari seseorang atau organisasi kelembagaan.

\section{Teknik Analisis Data}

Teknik analisis data yang digunakan dalam penelitian ini adalah analisis kualitatif yang 


\section{PEDAGOGIKA}

Volume 12 (Nomor 2) 2021

HaL. 245-263

dilakukan dengan menelaah dan mengkaji data yang diperoleh dari sumber-sumber yang terkait. Analisis data dilakukan dengan langkah-langkah yaitu: Reduksi data, Penyajian data, Penarikan kesimpulan atau verifikasi yang diperoleh melalui catatan hasil observasi dan hasil wawancara.

\section{HASIL DAN PEMBAHASAN}

\section{Hasil Penelitian}

\section{a. Upaya-Upaya Kepala Sekolah Membantu Guru Mengatasi Kesulitan Mengajarnya}

Upaya-upaya yang dilakukan kepala sekolah dalam membantu kesulitan mengajar guru dilakukan dengan pendekatan persuasif dengan menggabungkan guru yang dianggap mampu digabungkan ke group kelas lain, setiap kelas disiapkan laptop dan LCD di kelas, buku paket, pelatihan pembuatan video-video pembelajaran, mendesain pembelajaran yang menyenangkan, buku-buku dimodifikasi sesuai dengan kebutuhan untuk implemetasi 70/30, dan tersedianya jaringan listrik dan internet (WIFI) dan Indi Home. Sebagaimana yang disampaikan ibu Kepala Sekolah berikut ini.

'Dalam upaya mengatasi kesulitan mengajar guru, kami di sekolah ini melakukan pendekatan persuasif terhadap guru-guru dengan menggabungkan guru yang dianggap mampu dalam pembelajaran dengan group kelas lainnya. kemudian di setiap kelas disiapkan Laptop dan LCD. Kami juga mengupayakan berlangganan buku paket Erlangga dengan master Barcode. Di sekolah juga dilaksanakan pelatihan pembuatan videovideo pembelajaran, mendesain kegiatan pembelajaran yang menyenangkan, buku-buku dimodifikasi sesuai dengan kebutuhan untuk implemetasi 70/30, dan tersedianya jaringan listrik dan internet (WIFI) dan Indi Home" (W.F1.KS.01.08.2019).

Terkait dengan upaya-upaya yang dilakukan kepala sekolah dalam mengatasi kesulitan mengajar guru disampaikan pula oleh ibu guru wali kelas $\mathrm{V}$ berikut ini.

"Terkait dengan upaya kepala sekolah dalam mengatasi kesulitan mengajar guru biasanya melalui rapat disampaikan kendalakendala yang dihadapi guru-guru dalam mengajar dan secara umum hubungan dengan teman-teman guru lainnya di sekolah. Dalam kegiatan pembelajaran terkait dengan penggunaan IT dan komputer. Begitu juga kalau ada guru yang mengalami kesulitan dalam pembelajarannya akan dibantu oleh teman-teman guru yang dianggap mampu" (W. F1.HP.17.09.2019).

Pernyataan diatas juga sejalan dengan yang disampaikan oleh salah seorang guru mata pelajaran yang menyatakan bahwa:

'Kepala sekolah dalam upaya mengatasi kesulitan mengajar guru biasanya dengan mengadakan sosialisasi pada kegiatan rapat. Kepala sekolah memberikan kesempatan kepada guru untuk menyampaikan kesulitankesulitan yang dialami pada saat pembelajaran. Kepala sekolah selalu menganjurkan agar guru-guru menggunakan IT yang sudah disiapkan di sekolah. Kemudian secara sosial kepala sekolah selalu mengembangkan profesi guru baik di bidang pengetahuan maupun 


\section{PEDAGOGIKA}

Volume 12 (Nomor 2) 2021

HaL. 245-263

secara pribadi ( dalam kegiatan Diklat, Seminar yang diikuti oleh guru sesuai dengan bidang mata pelajaran), dan kepala sekolah juga selalu menyampaikan kepada guru-guru agar kegiatan pembelajaran selalu Update" (W.F1.TB.18.10.2019).

Jadi kepala sekolah senantiasa melakukan upaya-upaya dalam mengatasi kesulitan mengajar guru melalui rapat yang dilakukan pada setiap hari Jumat membahas masalahmasalah di dalam kelas, masalah umum atau masalah pribadi guru-guru.

Berdasarkan paparan data di atas dapat dikemukakan kesimpulan sementara penelitian bahwa upaya-upaya yang dilakukan kepala sekolah dalam membantu kesulitan mengajar guru di MIM Unggulan Kota Gorontalo adalah; membantu guru yang mengalami kesulitan mengajar dengan menggabungkan guru yang dianggap mampu ke group kelas dimana guru tersebut mengalami kesulitan dengan sharing ilmu; membantu dalam penggunaan model, metode, dan teknik pembelajaran; menyiapkan laptop dan LCD di kelas; penyediaan buku paket; pelatihan pembuatan video-video pembelajaran; mendesain pembelajaran yang menyenangkan; buku-buku dimodifikasi sesuai dengan kebutuhan untuk implemetasi 70/30; dan penyediaan jaringan listrik dan internet (WIFI) dan Indi Home.

\section{b. Upaya-Upaya Kepala Sekolah Dalam Melakukan Penilaian Terhadap Sasaran}

\section{Program Pengajaran Yang Disesuaikan Dengan Kebutuhan Belajar Peserta Didik Di MIM Unggulan Kota Gorontalo}

Upaya-upaya kepala sekolah dalam melakukan penilaian terhadap sasaran program pengajaran yang disesuaikan dengan kebutuhan belajar peserta didik di MIM Unggulan Kota Gorontalo sebagaimana yang disampaikan oleh salah seorang guru dalam wawancara yang dilakukan berikut ini.

"Kepala sekolah dalam melakukan penilaian terhadap sasaran program pengajaran dilakukan melalui kegiatan supervisi yang dimulai dengan supervisi kelengkapan administrasi pembelajaran guru, kemudian dilanjutkan dengan kegiatan supervisi di kelas. Pemantauan pelaksanaan pembelajaran guru juga dilakukan setiap hari melalui CCTV yang ada di masing-masing kelas yaitu kelas IV, V, dan VI.yang berada di gedung I. sedangkan untuk kelas I, II, dan III dilakukan pemantauan langsung ke kelas" (W.F2.HP.17.09.2019).

Kepala sekolah MIM Unggulan Kota Gorontalo melakukan penilaian terhadap sasaran program pengajaran melalui kegiatan supervisi yaitu supervisi administrasi dan supervisi kelas, dan pemantauan melalui CCTV dan pemantauan langsung ke kelas.

Sejalan dengan penyampaian informan sebelumnya mengenai upaya-upaya kepala sekolah dalam melakukan penilaian terhadap sasaran program pengajaran disampaikan pula bahwa: 


\section{PEDAGOGIKA}

Volume 12 (Nomor 2) 2021

HaL. 245-263

"Selain kegiatan supervisi dan pemantauan melalui CCTV dan pemantauan langsung ke kelas. Untuk siswa setiap hari ada bimbingan khusus terhadap siswa-siswa yang memiliki bakat dan potensi dalam rangka mengembangkan bakat dan minat mereka serta dalam rangka persiapan dalam mengikuti lomba. Hal ini dilakukan dalam rangka memenuhi kegiatan pembelajaran yaitu $70 \%$ untuk pemguatan karakter siswa, dan 30\% meningkatkan pengetahuan siswa. Lombalomba yang biasaya dikuti adalah lomba OSN, H2SN, Olimpiade Ahmad Dahlan, Matematika, Bercerita, Olah Raga, dan Tapak Suci. Dalam setahun bisa mencapai 5 lomba yang diikuti” (W.F2.TB.18.10.2019).

Berdasarkan paparan data di atas dapat dikemukakan kesimpulan sementara penelitian bahwa upaya-upaya kepala sekolah dalam melakukan penilaian terhadap sasaran program pengajaran telah dilakukan melalui supervisi administrasi dan supervisi kelas, pemantauan melalui CCTV dan pemantauan langsung ke kelas, dan setiap hari ada bimbingan khusus terhadap siswa-siswa yang memiliki bakat dan potensi dalam rangka mengembangkan bakat dan minat mereka serta dalam rangka persiapan dalam mengikuti lomba seperti; lomba OSN, H2SN, Olimpiade Ahmad Dahlan, Matematika, Bercerita, Olah Raga, dan Tapak Suci.

\section{c. Upaya-Upaya Kepala Sekolah Dalam Melakukan Perbaikan Program Pengajaran Yang Telah Direncanakan Di MIM Unggulan Kota Gorontalo}

Upaya-upaya kepala sekolah dalam melakukan perbaikan program pengajaran di MIM Unggulan Kota Gorontalo sebagaimana yang disampaikan melalui wawancara terhadap salah seorang guru yaitu:

"Dalam rangka perbaikan program pengajaran di MIM Kota Gorontalo agar sesuai dengan yang telah direncanakan untuk siswa diberikan bimbingan khusus yang apabila orang tuanya ingin mengikutkan anaknya bimbingan di bidang matematika, sains, tilawah dilakukan bimbingan 2 kali seminggu dalam kegiatan full day. Bimbingan khusus juga dilakukan bagi siswa-siswa yang memiliki keinginan sendiri mengikuti bimbingan".

(W.F3.TB.18.10.2019).

Selain yang disampaikan oleh informan sebelumnya disampaikan pula oleh salah salah seorang guru dalam hasil wawancara yang dilakukan berikut ini.

"Selain bimbingan khusus terhadap siswa yang membutuhkan. Di sekolah ini tentunya senantiasa mengikuti kurikulum yang berlaku. Agar penilaian terhadap siswa lebih obyektif di sekolah telah dikembangkan aplikasi dalam penilaian karakter siswa untuk menilai ulangan harian, dan tengah semester siswa".

(W.F3.HP.17.09.2019).

Berdasarkan paparan data di atas dapat dikemukakan kesimpulan sementara penelitian bahwa upaya-upaya kepala sekolah dalam melakukan perbaikan program pengajaran di MIM Unggulan Kota Gorontalo yaitu: memberikan bimbingan khusus bagi siswa yang orang tuanya ingin mengikutkan anaknya 


\section{PEDAGOGIKA}

Volume 12 (Nomor 2) 2021

HaL. 245-263

dalam bimbingan di bidang matematika, sains, tilawah, bimbingan khusus juga dilakukan bagi siswa-siswa yang memiliki keinginan sendiri, dan penilaian karakter siswa untuk menilai ulangan harian, dan tengah semester siswa.

\section{d. Upaya-Upaya Kepala Sekolah Melakukan Program-Program Perubahan Di Mim Unggulan Kota Gorontalo}

Upaya-upaya kepala sekolah dalam melakukan program-program perubahan di MIM Unggulan Kota Gorontalo sebagaimana yang disampaikan melalui wawancara terhadap kepala sekolah berikut ini.

"Program-program perubahan yang dilaksanakan di sekolah ini untuk tahun ajaran 2019-2020 yaitu untuk kegiatan supervisi administrasi dan pembelajaran setiap hari Senin guru-guru dipilih dan diacak, pengawasan dari kementerian agama diawal tahun ajaran, ada English dan Arabian day dan setiap pekan harus ada kata yang dikuasai, guru dan siswa setiap hari melakukan hafalan Qur'an juz 30, dan setiap 2 pekan sekali pada hari Jum'at ada kegiatan problem solving day". (W.F4.KS.01.08.2019).

Adapun program-program perubahan di MIM Unggulan Kota Gorontalo dalam pelaksanaan supervisi administrasi dan pembelajaran guru-guru dipilih dan diacak, ada pengawasan dari kementerian agama diawal tahun ajaran, ada English dan Arabian day dan setiap pekan harus ada kata yang dikuasai, hafalan Qur'an juz 30, dan kegiatan problem solving day.

Sejalan dengan penyampaian kepala sekolah dalam hasil wawancaranya, salah seorang guru juga menyampaikan tentang program-program perubahan yang dilaksanakan di MIM Unggulan Kota Gorontalo berikut ini.

"Dalam melakukan program-program perubahan di MIM Unggulan Kota Gorontalo kepala sekolah menjalin kerjasama dengan instansi diluar sekolah seperti kerjasama dengan MAN Insan Cendekia, perguruan tinggi (UNG), lembaga-lembaga bimbingan belajar dalam rangka peningkatan mutu sekolah. Siswa juga diberikan kebebasan untuk mengikuti bimbingan belajar di sekolah". (W.F4.TB.18.10.2019).

\section{Jadi di MIM Unggulan Kota Gorontalo} dalam melakukan program-program perubahan banyak melakukan kerjasama dengan pihakpihak terkait seperti sekolah, perguruan tinggi dan lembaga bimbingan belajar.

Berdasarkan paparan data di atas dapat dikemukakan kesimpulan sementara penelitian bahwa upaya-upaya kepala sekolah dalam melakukan program-program perubahan di MIM Unggulan Kota Gorontalo yaitu: kerjasama dengan pihak-pihak seperti sekolah, perguruan tinggi dan lembaga bimbingan belajar, raport digital, kultum setelah sholat Dzuhur dalam membiasakan siswa tampi berani di depan orang banyak, proaktif dalam 
PEDAGOGIKA

Volume 12 (Nomor 2) 2021

HaL. 245-263

mengikuti lomba-lomba seperti lomba OSN mulai dari kelas III, KSN yang dilaksanakan Kementerian Agama, Lomba Cepat Baca puisi dan dongeng yang dilaksanakan oleh Dinas Sosial., penilaian sikap berbasis IT melalui aplikasi Dojo Class dalam memudahkan guru menilai karakter siswa, absensi online, group kelas, tersedia akun untuk guru, siswa, dan orang tua dalam membantu memantau perkembangan siswa, dan program hafalan Qur'an juz 30.

\section{e. Upaya-upaya kepala sekolah melakukan evaluasi terhadap program-program pengajaran di MIM Unggulan Kota Gorontalo}

Upaya-upaya kepala sekolah dalam melakukan evaluasi terhadap programprogram pengajaran di MIM Unggulan Kota Gorontalo sebagaimana yang disampaikan melalui wawancara terhadap salah seorang guru yaitu:

'Untuk melakukan evaluasi terhadap program-program pengajaran dilaksanakan melalui rapat evaluasi dalam hal ini membahas tentang kendala terhadap program pengajaran yang telah direncanakan. Ini dilakukan karena biasanya guru-guru hanya semangat di awal sehingga perlu ada evaluasi”. (W.F5.AR.12.11.2019).

Berdasarkan paparan data di atas dapat dikemukakan kesimpulan sementara penelitian bahwa upaya-upaya kepala sekolah dalam melakukan evaluasi terhadap program- program pengajaran dii MIM Unggulan Kota Gorontalo yaitu: rapat evaluasi dalam hal ini membahas tentang kendala terhadap program pengajaran yang telah direncanakan, dan kegiatan Problem Solving setiap hari Ju'mat dalam mengatasi masalah-masalah guru dalam kegiatan pembelajaran dan masalah lainnya yang dihadapi guru. 
PEDAGOGIKA

Volume 12 (Nomor 2) 2021

HaL. 245-263

Adapun diagram konteks temuan akhir

penelitian dapat dilihat pada gambar berikut.

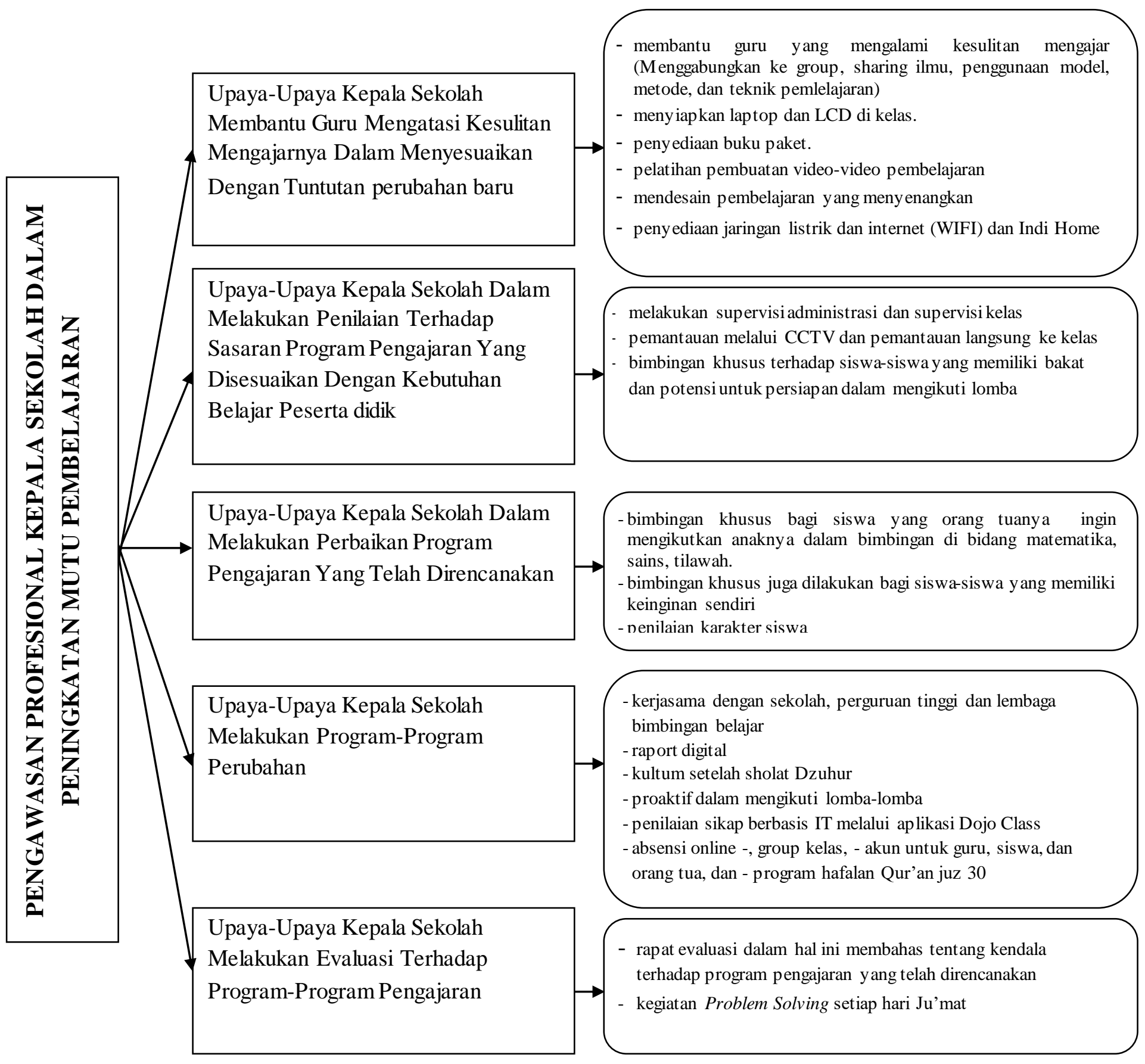

\section{Gambar 1. Pengawasan Profesional Kepala Sekolah Dalam Peningkatan Mutu Pembelajaran Guru Di MIM Unggulan Kota Gorontalo}




\section{Pembahasan}

a. Upaya-Upaya

Kepala

Sekolah

Membantu Guru Mengatasi Kesulitan

Mengajarnya Dalam Menyesuaikan

Dengan Tuntutan Perubahan Baru Di

Mim Unggulan Kota Gorontalo

Upaya-upaya kepala sekolah membantu guru mengatasi kesulitan mengajarnya dalam menyesuaikan dengan tuntutan perubahan baru di MIM Unggulan Kota Gorontalo dilakukan dengan berbagai macam cara yaitu: membantu guru yang mengalami kesulitan mengajar dengan menggabungkan guru yang dianggap mampu ke group kelas dimana guru tersebut mengalami kesulitan dengan sharing ilmu; membantu dalam penggunaan model, metode, dan teknik pembelajaran; menyiapkan laptop dan LCD di kelas; penyediaan buku paket; pelatihan pembuatan video-video pembelajaran; mendesain pembelajaran yang menyenangkan; buku-buku dimodifikasi sesuai dengan kebutuhan untuk implemetasi 70/30; dan penyediaan jaringan listrik dan internet (WIFI) dan Indi Home.

Berbagai bantuan professional yang telah diberikan oleh kepala sekolah MIM Kota Gorontalo dalam rangka mengatasai kesulitan mengajar guru serta dalam rangka meningkatkan mutu pembelajaran ini sejalan dengan pendapat Suhardan (2018) bahwa bantuan dapat berupa perbaikan teknis metodologis pembelajaran, pemecahan kesulitan individual, pengayaan atau pengembangan kurikulum, penguasaan materi ajar, pembuatan lembar kerja, penggunaan sumber belajar maupun pemilihan buku teks. Apabila guru selama bertugas tidak memperoleh bantuan profesional yang teratur, sangat mungkin pada suatu saat pengetahuan, keterampilan, dan kemampuan yang dimiliki sebagai bekal pendidikan pra jabatan tidak lagi berkembang atau terhenti karena keletihan, kejenuhan, atau kebosanan bahkan mungkin terjadi penurunan prestasi. Hal seperti ini sangat merugikan bagi usaha peningkatan mutu pendidikan.

\section{b. Upaya-Upaya Kepala Sekolah Dalam Melakukan Penilaian Terhadap Sasaran Program Pengajaran Yang Disesuaikan Dengan Kebutuhan Belajar Peserta Didik Di MIM Unggulan Kota Gorontalo}

Upaya-upaya kepala sekolah dalam melakukan penilaian terhadap sasaran program pengajaran yang disesuaikan dengan kebutuhan belajar peserta didik di MIM 


\section{PEDAGOGIKA}

Volume 12 (Nomor 2) 2021

HaL. 245-263

Unggulan Kota Gorontalo yaitu: melakukan supervisi administrasi dan supervisi kelas, pemantauan melalui CCTV dan pemantauan langsung ke kelas, dan setiap hari ada bimbingan khusus terhadap siswa-siswa yang memiliki bakat dan potensi dalam rangka mengembangkan bakat dan minat mereka serta dalam rangka persiapan dalam mengikuti lomba seperti; lomba OSN, H2SN, Olimpiade Ahmad Dahlan, Matematika, Bercerita, Olah Raga, dan Tapak Suci.

Menurut Masaong (2012). ada beberapa aspek penting dalam kegiatan supervisi yaitu: (1) bersifat bantuan dan pelayanan kepala sekolah kepada guru dan staf, (2) untuk pengembangan kualitas guru, (3) untuk pengembangan profesional guru, dan (4) untuk memotivasi guru. Beberapa aspek yang dimaksud tersebut adalah sebagai tuntutan pengetahuan tentang konsep dan pendekatan supervisi yang ditunjang dengan kinerja dan akuntabilitas yang tinggi dari supervisor. Dalam hal ini dimaksudkan agar kegiatan supervisi sebagai layanan profesional dapat meningkatkan kompetensi guru dalam pembelajaran yang bermuara pula pada perwujudan hasil belajar peserta didik secara optimal.

Sedangkan menurut Satori (dalam Suhardan, 2010) bahwa supervisi akademik menitikberatkan pada pengamatan supervisor/ kepala sekolah pada masalah-masalah akademik, yaitu hal-hal yang langsung berada pada lingkungan kegiatan pembelajaran pada waktu siswa sedang dalam proses mempelajari sesuatu dalam hal ini sasarannya adalah meningkatkan mutu proses pembelajaran dan hasil pembelajaran. Proses ini dipengaruhi oleh banyak faktor terutama guru dan peserta didik, program kurikulum yang digunakan, buku teks, fasilitas belajar dan media belajar termasuk alat peraga, kultur sekolah serta lingkungannya, sehingga supervisi harus ditujukan untuk memperbaiki dan meningkatkan situasi belajar mengajar.

\section{c. Upaya-upaya kepala sekolah dalam melakukan perbaikan program pengajaran yang telah direncanakan di MIM Unggulan Kota Gorontalo}

Upaya-upaya kepala sekolah dalam melakukan perbaikan program pengajaran yang telah direncanakan di MIM Unggulan Kota Gorontalo yaitu: memberikan bimbingan khusus bagi siswa yang orang tuanya ingin mengikutkan anaknya dalam bimbingan di bidang matematika, sains, tilawah, bimbingan khusus juga dilakukan bagi siswa-siswa yang memiliki keinginan sendiri, dan penilaian karakter siswa untuk menilai ulangan harian, 


\section{PEDAGOGIKA}

Volume 12 (Nomor 2) 2021

HaL. 245-263

dan tengah semester siswa. Hal tersebut dilakukan hal pemberdayaan guru.

Menurut .Suhardan (2010) pemberdayaan guru merupakan usaha untuk mempertinggi kecakapan guru dalam mengemban profesinya. Pemberdayaan guru profesional merupakan suatu usaha agar guru memperoleh kewenangan mengajar sesuai standar profesional. Kemampuan mengajar guru perlu memperoleh pembinaan supaya mereka memiliki kewenangan mengajar sesuai dengan tuntutan zaman. Di era ini guru dituntut lebih kritis dan aktif dalam menjalankan tugasnya, pembinaan terhadap mereka menjadikan guru bukan sekedar pelaksana teknis, melainkan seorang petugas profesional yang mengerti dan memahami bagaimana seharusnya memberi layanan belajar kepada peserta didiknya. Guru yang berdaya mempunyai kepekaan terhadap kebutuhan peserta didiknya, dan sanggup mencari solusi dari kesulitan mengajar yang dihadapinya. Hal ini disebabkan tugas guru sehari-hari melaksanakan layanan belajar kepada peserta didik sesuai dengan tujuan pendidikan yang dituangkan kedalam kurikulum, menyajikannya berdasarkan metode mengajar dan menilai kemajuan untuk mengetahui ketercapainnya. Bila mereka tidak diberdayakan, maka guru akan larut dalam sistem yang rutin, sehingga tidak mustahil akan

mengalami kejenuhan dan prestasinya akan menurun karena kraetivitasnya menjadi tumpul.

\section{d. Upaya-Upaya Kepala Sekolah Melakukan Program-Program} Perubahan Di Mim Unggulan Kota Gorontalo

Upaya-upaya kepala sekolah melakukan program-program perubahan di MIM Unggulan Kota Gorontalo yaitu: kerjasama dengan pihak-pihak seperti sekolah, perguruan tinggi dan lembaga bimbingan belajar, raport digital, kultum setelah sholat Dzuhur dalam membiasakan siswa tampi berani di depan orang banyak, proaktif dalam mengikuti lomba-lomba seperti lomba OSN mulai dari kelas III, KSN yang dilaksanakan Kementerian Agama, Lomba Cepat Baca puisi dan dongeng yang dilaksanakan oleh Dinas Sosial., penilaian sikap berbasis IT melalui aplikasi Dojo Class dalam memudahkan guru menilai karakter siswa, absensi online, group kelas, tersedia akun untuk guru, siswa, dan orang tua dalam membantu memantau perkembangan siswa, dan program hafalan Qur'an juz 30.

Upaya-upaya kepala sekolah tersebut adalah merupakan faktor penting dalam melakukan perubahan di sekolah. Dalam hal perubahan ini sejalan dengan pendapat Sobri (2013) bahwa 


\section{PEDAGOGIKA}

Volume 12 (Nomor 2) 2021

HaL. 245-263

kepala sekolah memiliki tugas untuk dilakukan menurut Lipham (dalam Sagala, meningkatkan keberhasilan keseluruhan 2012) terkait dengan evaluasi terhadap proses program pembelajaran sekolah dan kemajuan guru dan siswa. Hal ini dilakukan oleh kepala sekolah melalui penekanan program pengajaran yaitu: (1) assessing program objectives, penilaian terhadap sasaran program, pembelajaran yang unggul, mendiagnosa kepala sekolah perlu menguji apakah program program pembelajaran berkelanjutan, berdiskusi mengenai program pembelajaran dengan guru, dan membantu guru dalam mengidentifikasi tujuan pembelajaran serta gagasan dan pengalaman dengan guru tentang kurikulum dan masalah pembelajaran lain.

e. Upaya-upaya kepala sekolah melakukan evaluasi terhadap program-program pengajaran di MIM Unggulan Kota

\section{Gorontalo}

Upaya-upaya kepala sekolah melakukan evaluasi terhadap program-program pengajaran di MIM Unggulan Kota Gorontalo yaitu: rapat evaluasi dalam hal ini membahas tentang kendala terhadap program pengajaran yang telah direncanakan, dan kegiatan Problem Solving setiap hari Ju'mat dalam mengatasi masalah-masalah guru dalam kegiatan pembelajaran dan masalah lainnya yang dihadapi guru.

Penting bagi kepala sekolah untuk memperhatikan pelaksanaan evaluasi tehadap program pengajaran. Beberapan hal yang perlu pengajaran sudah sesuai dengan kebutuhan belajar peserta didik, (2) planning program improvement, perbaikan program-program yang direncanakan dengan cara membentuk struktur kerja yang tepat, menghimpun informasi dan data-data yang akurat mengenai pembelajaran dan memanfaatkannya untuk melakukan perbaikan dan penyusunan program sesuai spesifikasi sumber-sumber yang diperlukan oleh program, (3) implementing program change, melakukan program-program perubahan dengan cara memotivasi para guru untuk menggunakan strategi pengajaran yang lebih menarik dan interaktif, memotivasi staf sekolah untuk memberikan layanan yang terbaik dalam mendukung lancarnya kegiatan belajar dan mengajar, dan memotivasi masyarakat sekolah untuk memberi dukungan penuh terhadap program-program peningkatan mutu pmbelajaran di sekolah, dan (4) evaluation of program change, melakukan evaluasi terhadap program-program apakah telah terjadi perubahan dengan cara mengukur outcomes dari pengajaran yang telah dilakukan. 


\section{PEDAGOGIKA}

Volume 12 (Nomor 2) 2021

HaL. 245-263

\section{SIMPULAN}

Berdasarkan temuan penelitian, maka dirumuskan kesimpulan berikut ini. UpayaUpaya Kepala Sekolah Membantu Guru Mengatasi Kesulitan Mengajarnya Dalam Menyesuaikan Dengan Tuntutan Perubahan Baru Di Mim Unggulan Kota Gorontalo meliputi: membantu guru yang mengalami kesulitan mengajar (Menggabungkan ke group, sharing ilmu, penggunaan model, metode, dan teknik pemlelajaran), menyiapkan laptop dan LCD di kelas, penyediaan buku paket, pelatihan pembuatan video-video pembelajaran, mendesain pembelajaran yang menyenangkan, dan penyediaan jaringan listrik dan internet (WIFI) dan Indi Home. UpayaUpaya Kepala Sekolah Dalam Melakukan Penilaian Terhadap Sasaran Program Pengajaran Yang Disesuaikan Dengan Kebutuhan Belajar Peserta Didik Di MIM Unggulan Kota Gorontalo meliputi: melakukan supervisi administrasi dan supervisi kelas, pemantauan melalui CCTV dan pemantauan langsung ke kelas, bimbingan khusus terhadap siswa-siswa yang memiliki bakat dan potensi untuk persiapan dalam mengikuti lomba. Upaya-upaya kepala sekolah melakukan program-program perubahan di MIM Unggulan Kota Gorontalo meliputi: bimbingan khusus bagi siswa yang orang tuanya ingin mengikutkan anaknya dalam bimbingan di bidang matematika, sains, tilawah, bimbingan khusus juga dilakukan bagi siswa-siswa yang memiliki keinginan sendiri, penilaian karakter siswa. Upaya-upaya kepala sekolah melakukan program-program perubahan di MIM Unggulan Kota Gorontalo meliputi: kerjasama dengan sekolah, perguruan tinggi dan lembaga bimbingan belajar, raport digital, kultum setelah sholat Dzuhur, proaktif dalam mengikuti lomba-lomba, penilaian sikap berbasis IT melalui aplikasi Dojo Class, absensi online, group kelas, akun untuk guru, siswa, dan orang tua, dan program hafalan Qur'an juz 30. Upaya-upaya kepala sekolah melakukan evaluasi terhadap programprogram pengajaran di MIM Unggulan Kota Gorontalo meliputi: rapat evaluasi dalam hal ini membahas tentang kendala terhadap program pengajaran yang telah direncanakan, dan kegiatan Problem Solving setiap hari Ju'mat.

\section{REFERENSI}

Bogdan, R.C. \& Biklen, S.K.1998. Qualitative Research for Education: An Introduction to Theory and Methods. Boston: Allyn and Bacon, Inc.

Maisyaroh, dkk. 2014. Masalah Guru dalam Impelementasi Kurikulum 2013 dan Kerangka Model Supervisi Pengajaran. 
PEDAGOGIKA

Volume 12 (Nomor 2) 2021

HaL. 245-263

Jurnal Manajemen Pendidikan. Volume 24 : 213-220. ISSN 0852-1921.

Masaong. A.K. 2012. Supervisi Pembelajaran dan Pengembangan Kapasita Guru (Memberrdayakan Pengawas Sebagai Gurunya Guru). Bandung: Alfabeta.

Miles, M.B., Huberman, A.M. 1992. Analisis Data Kualitatif: Buku Sumber Tentang Metode-Metode Baru. Penerjemah, Tcecep Rohendi Rohidi. Jakarta: UIPress.

Moleong, L.J. 2002. Metodologi Penelitian Kualitatif. Bandung: PT Remaja Rosdakarya

Sagala, Syaiful. 2012. Supervisi Pemebelajaran dalam Profesi Pendidikan. Bandung: Alfabeta.

Sahertian, Piet.A. 2008. Konsep Dasar dan Teknik Supervisi Pendidikan Dalam Rangka Pengembangan Sumber Daya Manusia. Jakarta: Rineka Cipta.

Sobri, A.Y. 2013. Pembinaan Profesionalisme Guru dalam Meningkatkan Kualitas Pembelajaran. Jurnal Manajemen Pendidikan. Volume 24:9-10. ISSN 0852-1921.

Suhardan, Dadang. 2010. Supervisi Profesional (Layanan Dalam Meningkatkan Mutu Pembelajaran di Era Otonomi Daerah). Bandung : Alfabeta.

Purwanto M.N. Administrasi dan Supervisi Pendidikan. Bandung: PT Remaja Rosdakarya.

Ulfatin, Nurul. 2013. Metode Penelitian Kualitatif Di Bidang Pendidikan: Teori
Dan Aplikasinya. Malang: Bayumedia Publishing.

Usman, M.U. 2009. Menjadi Guru Profesional. Bandung : PT. Remaja Rosdakarya.

Wahjosumidjo. 2007. Kepemimpinan Kepala Sekolah (Tinjauan Teoretik dan Permasalahannya). Jakarta: PT Rajagrafindo Persada. 